\title{
O ALGODÃO BRASILEIRO NA ÉPOCA DA REVOLUÇÃO INDUSTRIAL*
}

\section{BRAZILIAN RAW COTTON IN THE EPOCH OF THE INDUSTRIAL REVOLUTION}

\author{
José Jobson de Andrade Arruda \\ Universidade de São Paulo, São Paulo, Brasil, jobson.a@uol.com.br
}

\begin{abstract}
Resumo. Há pouca discordância entre os especialistas sobre o papel do algodão no contexto da revolução industrial em sua escala europeia. Tergiversam apenas sobre o grau de importância desta matéria-prima estratégica no lançamento da industrialização, considerando-se que a dinâmica dessa indústria tornou-se referência vital na determinação da taxa de aceleração do ramo têxtil e de seu impacto sobre os demais setores da indústria, que nos permite identificar este setor como revolucionário. A manufatura de algodão foi de grande importância não apenas para a Inglaterra, mas também para outros países continentais como França e Portugal nos quais, no princípio do século XIX, o dinamismo das manufaturas têxteis intensificou-se, despertando o interesse público e privado em alçá-las do nível de manufaturas pré-industriais ao patamar de estruturas produtivas modernas, configurando-se um contexto histórico singular que denominamos a época da revolução industrial.
\end{abstract}

Palavras chave: algodão; revolução industrial; colônias; metrópoles.

Abstract. There is little disagreement between specialists over the role of raw cotton in the context of Industrial Revolution in Europe. There is much discussion about the importance's level of this strategic commodity in the beginning of industrialization, considering that dynamics of this industry has become vital reference in the determination of the acceleration rate of the textile segment and its impact on the others industry sectors, which allows us to identify this sector as revolutionary. The raw cotton manufacture was of great importance not only to England, but also to other continental countries such as France and Portugal, in which, in the early nineteenth century, the textile manufactures dynamism escalated, rising the public and private interest in elevating the pre-industrial manufactures to modern productive structure, setting, thus, these specific historical context as the Industrial Revolution period.

Key words: raw cotton; Industrial Revolution; colonies; metropolis.

Artigo recebido: 4 de maio de 2015. Artigo aceito: 3 de agosto de 2015.

* Projeto de Pesquisa CNPq (2009-2015), O Brasil na Revolução Industrial (1790-1850), pesquisador 1A. Agradeço as valiosas sugestões oferecidas pelos pareceristas que em muito contribuíram para o aprimoramento do trabalho; o esmero de Luís Otávio Pagano Tasso na formatação do artigo e a prestimosa revisão de Leandro Vizin Villarino.

Am. Lat. Hist. Econ., mayo-agosto, 2016, pp. 167-203 | DOI: 10.18232/alhe.v23i2.712 


\section{ProposiçÃo}

análise do papel desempenhado pelo algodão no processo de indus-
trialização não pode ser realizada isoladamente. Deve ser efetuada
de modo integrado, pois os países envolvidos, Inglaterra, França e Portugal, e outros mais em menor escala, são atores políticos centrais nas conflitivas relações internacionais que marcam a história europeia entre o final do século XVIII e início do século XIX. Sobretudo porque não se pode separar o conflito político do interesse econômico das nações envolvidas, a batalha renhida por espaços de hegemonia política que significavam, em última instância, o embate pela conquista de mercados externos cativos e, por isso mesmo, capazes de alavancar o crescimento econômico interno das economias nacionais europeias.

Jogo complexo que envolvia, de um lado, Estados poderosos com longa tradição de conflito diplomático e enfrentamento militar em prol da hegemonia no concerto europeu, França e Inglaterra, e, do outro, Portugal, Reino decadente com um vasto império cobiçado pelas potências em ascensão. De comum, entre os três, o fato de não produzirem a matéria-prima vital em seus próprios territórios continentais, sendo todos dependentes das importações oriundas de suas colônias ultramarinas, contexto no qual Portugal e Inglaterra eram os atores privilegiados. $\mathrm{O}$ primeiro, por deter o controle de uma vasta colônia na América onde o algodão era planta nativa. O segundo, a Inglaterra, por ter domínio sobre as treze colônias americanas, especialmente as do Sul, igualmente produtoras de algodão em rama; por contarem com a imensa reserva territorial representada pelas aquisições coloniais realizadas no decurso do século XVIII, notadamente a India, tradicional espaço de cultivo da fibra e de manufaturas têxteis de alta qualidade. De outro lado, a França que, exatamente por ter perdido grande parte de seu Império marítimo asiático para a própria Inglaterra no decurso das guerras europeias da segunda metade do século XVIII, ficara desprovida da matéria-prima indiana; passara a ter dificuldades para acessar o mercado egípcio; perdera o controle da parte Sul do continente norte-americano para os ingleses primeiro, e para os próprios norte-americanos após as guerras de Independência das treze colônias, que passaram a controlar e fazer política com a matéria-prima extremamente valorizada num contexto de alta belicosidade. Período no qual a elevação dos preços, "acima de 100\%, ou mesmo 200\%, tornou-se comum” (O’Rourke, 2006, p. 146). Cenário que acabou por projetar o Brasil, colônia de Portugal, à condição de centro nevrálgico das disputas que na Europa se desenrolavam, envolvendo num vendaval o Reino português ameaçado de, a um só tempo, submergir no mapa político da Europa e 
perder a parte mais valiosa de seu império: a colônia brasileira, por todos reconhecida como a joia da coroa.

É neste entrechoque de forças poderosas que se pode entender a transmigração da Família Real portuguesa para o Brasil em 1808 e seus desdobramentos inevitáveis: a abertura dos portos brasileiros às nações amigas, equivale dizer, para a Inglaterra, e a assinatura dos Tratados Comerciais de 1810 com os britânicos, eventos políticos e econômicos de alta voltagem que sintetizam este momento convulsionado da história europeia e do Atlântico Sul.

\section{Circunstanciamento}

Evento sem paralelo na história da civilização ocidental, a mudança de toda uma corte, com todos os seus pertences, para o outro lado do oceano Atlântico. Uma migração forçada de 15000 indivíduos, de elevada condição social, que subitamente lotam as naus portuguesas para uma longa travessia oceânica para serem precariamente alojados na capital de seu Vice-reino, o Rio de Janeiro. A transferência da quase totalidade do aparato burocrático e administrativo do Estado, de todo arsenal indispensável ao exercício do poder em terras longínquas, que os próprios reis jamais haviam visitado em três séculos de dominação. Evento incomparável, que um insigne historiador brasileiro denominou por cortes em fuga, ao referir-se ao convulsionado ambiente político europeu no qual se inseria:

o rei da Hespanha mendigando em solo Francês a proteção de Napoleão; o rei da Prússia foragido da sua capital ocupada pelos soldados franceses; o Stathouder, quase rei da Holanda, refugiado em Londres; o rei das Duas Sicílias exilado na sua linda Nápoles; as dinastias da Toscana e Parma, errantes; o rei do Piemonte reduzido à mesquinha corte de Cagliari [...]; o czar celebrando entrevistas e jurando amizade para se segurar em Petersburgo; a Escandinávia prestes a implorar um herdeiro dentre os marechais de Bonaparte; o imperador do Sacro Império e o próprio Pontífice Romano obrigados, de quando em vez, a desamparar seus tronos que se diziam eternos e intangíveis (Lima, 1996, p. 149).

Evasões estas que têm em comum o fato de serem historicamente depressivas, pois nenhuma delas foi capaz de criar uma nação em território colonial; refundar um Estado na forma de um Reino Unido ao seu apêndice colonial; reconstruir um Império sediado em terras tropicais; conter os ventos do republicanismo que enorme fascínio exercia sobre as elites intelectualizadas da América, uma realidade concreta face aos projetos inconclusos de Carlos IV e seu herdeiro, o futuro Fernando VII, de transla- 
dar-se ao México, numa tentativa de fuga ao destino inglório que acabou por tragá-los.

Esta convulsão no mapa político e territorial da Europa, com impacto sobre suas extensões territoriais, não foi o resultado de condições geradas numa temporalidade breve, fruto de circunstâncias fortuitas. Foi o resultado de uma longa duração histórica cujos sinais espocam de forma perceptível durante todo o século XVIII, sinais críticos cujas manifestações se intensificaram em sua segunda metade. $\mathrm{O}$ embate franco-britânico ganhou intensidade paroxística no final da centúria, transformando a disputa entra duas nações num conflito europeu pelo inevitável envolvimento dos principais Estados continentais, abrangendo desde as ilhas britânicas até os confins das planícies russas, do estreito de Gibraltar aos contrafortes escandinavos, adquirindo as feições de uma conflagração mundial ao espraiar-se por latitudes e longitudes planetárias, pelo fato de estenderem-se aos impérios coloniais a eles conectados espalhados por todos os continentes, especialmente, os afro-asiático-americanos.

Rompendo a clássica política de equilíbrio que matizara as relações internacionais durante toda a primeira parte da época moderna, caracterizada pelas hegemonias circunstanciais de curta e média duração, busca-se neste momento a hegemonia absoluta, a primazia de uma só potência elevada à categoria de poder unipolar. É esta supremacia que se decide nos conflitos armados iniciados com as guerras da revolução francesa e do império napoleônico, primazia que se buscava alcançar a partir do domínio territorial ou marítimo, um período de 22 anos demarcado pelas balizas 1793-1815. O projeto napoleônico assentava-se no pressuposto de que seria possível "vencer o mar pelo poderio da terra"; exatamente o oposto do que projetavam os estrategistas ingleses do Foreign Office e do almirantado, a certeza de que o domínio sobre as massas líquidas garantidas pela Royal Navy dar-lhes-ia o controle das rotas interoceânicas e, por via de consequência, o domínio dos mercados continentais e suas ramificações. Sua confiança lastreava-se no excepcional poderio marítimo, pois, por volta de 1800, os "britânicos possuíam mais do que o dobro do número de navios de guerra que os franceses" (Davis e Engerman, 2006, p. 27).

Tudo isto num contexto em que o comércio exterior passava por mudanças significativas. Pela primeira vez na história do comércio exterior o mercado europeu deixava de ser majoritário para as exportações britânicas, sendo gradativamente deslocado pelos mercados coloniais. Sem eles, seria absolutamente impossível dar vazão ao crescimento acelerado da indústria têxtil, especialmente do setor algodoeiro, pois este setor era responsável por 53\% do crescimento total das exportações inglesas no período que transcorre entre 1786 e 1816 . No auge do conflito franco-britânico, entre 1804 e 1806, o comércio de tecidos de algodão atingiu $42 \%$ do total 
das exportações e, no biênio seguinte, $66 \%$. Nestes termos, seria absolutamente impossível manter o ritmo do crescimento industrial sem o correspondente ingresso da matéria-prima essencial. Situação agravada por uma circunstância inesperada, a perda do mercado colonial das treze colônias norte-americanas que obrigou os ingleses a baixarem um novo Ato de Navegação, no ano de 1786, cuja finalidade primordial era a intensificação do controle sobre os mercados fornecedores da matéria-prima estratégica, caso do algodão brasileiro, pois a continuidade do desenvolvimento das manufaturas têxteis "teria sido inconcebível sem o suprimento garantido de matérias-primas da Ásia e das Américas” (O’Brien, 1982, p. 11).

Assertiva que aponta no sentido da caracterização da revolução industrial como um fenômeno de amplo espectro, para além de considerá-la apenas uma "macroeconomic epoch" (Greasley e Oxley, 1994, pp. 760768). Isto porque não seria possível pensá-la nos estreitos limites de frios indicadores estatísticos sobre a produção, a produtividade, a proporção de capital investido ou o nível da poupança realizada, como advogam as perspectivas gradualistas (Crafts, 1985). Exige o alargamento do cenário pela inclusão da incontornável dimensão social, relacionadas às mudanças no mundo do trabalho, especialmente o trabalho feminino e infantil; na especialização regional; nas alterações demográficas, como querem M. Berg e P. Hudson (1992, pp. 24-50). Conjunto significativo ao qual poderíamos aduzir a dimensão política, a relação necessária entre as transformações produzidas pela revolução inglesa e o arranque industrial (Arruda, 1980, capítulo III), porque transformou o Parlamento num instrumento político da ação econômica, seja na transformação da estrutura agrária, seja na legislação específica relacionada à indústria têxtil (O'Brien, Griffiths e Hunt, 1991, pp. 395-423). Postura analítica que permite interpretar esta época singular em função da extensão e da univocidade das transformações econômicas e sociais havidas, de seu impacto sobre a história mundial em sua totalidade, centros e periferias, como, de resto, já fora sobejamente apontado por Eric Hobsbawm (1978).

Estreita-se, nesse sentido, a conexão entre guerra e economia, entre gastos militares e dispêndios do tesouro, estabelecendo-se uma íntima correlação entre fiscalidade e geopolítica do Império. Crescem os investimentos necessários à guerra a 90\% da totalidade dos gastos públicos, obrigando as autoridades governamentais a uma elevação vertiginosa dos impostos para suprir as necessidades do tesouro que, neste contexto, passava a consumir $60 \%$ da receita tributária. Montante nunca dantes imaginado, mas indispensável ao financiamento do trem de guerra maximamente representado pelos dispêndios navais, um desembolso monetário colossal destinado a prover uma média de 700 navios em ação permanente, para os quais era necessário, afora despesas de construção e manutenção, a re- 
muneração de 120000 homens pagos pelos cofres públicos, investimentos que se revelaram produtivos em si mesmos, pois, para os 166 navios perdidos nas contenda do período, outros 1200 foram capturados (O'Brien, 1982, pp. 50-51).

É exatamente neste contexto que a voltagem histórica dos territórios coloniais se eleva, pois são projetados à primeira cena do movimento da história, resgatados da condição de coadjuvantes a que tinham sido por séculos relegados. Caso exponencial da colônia brasileira, transformada em riqueza maior do império português, produtora estratégica de matérias-primas essenciais para os países europeus em franco processo de expansão industrial. É isso que designamos por fenômeno Brasil. O salto vertiginoso de uma colônia que rompe a tradicional monoexploração, seja dos metais e pedras preciosas, seja da monocultura canavieira, e diversifica sua produção agropastoril, expandindo a exportação de matérias-primas industriais, especialmente couros e algodão, e alimentos, todos essenciais ao desenvolvimento manufatureiro. Configura-se uma colônia modernizada, que, ao mesmo tempo, fornecia os insumos necessários à indústria e consumia os produtos manufaturados pelas metrópoles europeias (Arruda, 1980, pp. 604-621). Participa, portanto, da aceleração no ritmo do crescimento econômico das economias centrais, particularmente da britânica. Um momento de aceleração que rompe o gradualismo que transparece nas interpretações vazadas nos dados macroeconômicos captados na longa duração bissecular que vai de 1660 a 1860 (Crafts, 1985), período no qual se reconhece o lugar destacado da indústria algodoeira, posto que era responsável por $60 \%$ do crescimento da produtividade da indústria britânica no período, à frente da indústria siderúrgica e dos transportes. Indústria de longa tradição que remonta aos meados do século XVII, quando os artesãos ingleses, já familiarizados com a qualidade e as potencialidades comerciais da fibra de algodão, produziam fios, tecidos e têxteis acabados a partir da matéria-prima pura, ou da sua mescla com linho, lã ou seda, originando produtos diferenciados e com larga aceitação no mercado (O'Brien, Griffiths e Hunt, 1991, p. 395).

É no contexto do casamento entre a hegemonia industrial dos têxteis de algodão no desempenho econômico da Inglaterra e a expansão agrícola da colônia brasileira, especialmente da oferta de algodão em rama, que se dá a migração da Corte portuguesa para o Brasil. Transferência que, diga-se de passagem, poderia ser preterida em favor opções muito mais próximas de Portugal, no próprio espaço do império, a exemplo da Ilha da Madeira e dos Açores. Alternativas que não deixaram de ser cogitados na oportunidade, mas que foram descartadas em função do projeto longamente acalentado pelo Foreign Office britânico, ou seja, o estabelecimento de uma conexão direta entre Londres e o Rio de Janeiro, entre a 
Inglaterra e a colônia Brasil, de modo a eliminar o papel de intermediário secularmente exercido por Lisboa. A consciência dessa necessidade foi lentamente se formando a partir de um marco simbólico, o ano de 1776, com a perda das treze colônias norte-americanas, principal mercado externo colonial da economia britânica. Data que, coincidentemente, sinaliza a inversão da balança de comércio britânica em relação a Portugal. Déficits acumulados que se estendem pelo quinquênio 1776-1780, obrigando o tesouro britânico a enviar recursos monetários para Portugal, algo inimaginável para as autoridades financeiras britânicas até aquele momento, visto estarem acostumadas a receber polpudas transferências líquidas de Portugal na forma de metais preciosos para cobrir seus déficits seculares. Testemunho inequívoco de que a política de substituição de importações através do desenvolvimento manufatureiro, implantada pelo Marquês de Pombal nos meados do século, havia frutificado e, para cujo êxito, contribuíra de forma decisiva o mercado colonial brasileiro, convertido em complemento perfeito para a economia metropolitana.

Os ingleses acusaram o golpe, mas consideraram-no passageiro, produto de uma conjuntura desfavorável que logo passaria. Avaliação equivocada, porque o déficit repetiu-se no quinquênio 1791-1795, demonstrando ser a expressão de uma tendência estrutural, conforme se pode depreender de tabela elaborada por Sandro Sideri (1978, p. 332). Nela constata-se que o comércio com Portugal sempre fora totalmente superavitário para a Inglaterra durante a maior parte do século XVIII, com períodos excepcionais, a exemplo do quinquênio 1756-1760, quando o superávit britânico ultrapassou a casa de um milhão de libras esterlinas. É exatamente pela tradição superavitária do comércio exterior britânico em relação a Portugal que esta repetição do déficit na última década do século causa enorme apreensão no governo britânico, registrada com espanto por Robert Walpole em carta enviada lord Greenville, onde afirmava que o evento deveria ser observado como "a kind of phenomenon" (Maxwell, 1993, p. 229). Ou seja, algo que aparentemente não tinha explicação racional e que, para a infelicidade das autoridades governamentais inglesas viria a se repetir nos quinquênios sucessivos, 1801-1805 e 1805-1810 (Arruda, 2008, p. 74), confirmando a tendência estrutural. Os déficits acumulados promoveram uma drenagem significativa de recursos monetários rumo a Portugal, pois, ironia da história, peças de ouro reluzentes estampadas com a efígie de D. João VI, remetidas para a Inglaterra para o pagamento de déficits, passaram a retornar aos cofres portugueses. Peças de ouro reluzentes que as minas brasileiras produziram, os portugueses esbanjaram, e o novo produto rei da pauta de exportação colonial fazia retornar às arcas portuguesas: o algodão. 
Que motivos determinaram esta inversão estrutural? Sem dúvida, as motivações mais consistentes encontravam-se no Brasil. Era o denominado fenômeno Brasil, já referido. Reflexo da instalação na colônia brasileira de um renovado padrão de colonização que, por sua vez, gerou um novo padrão de acumulação, produto da crescente internalização do fluxo de renda e consequente endogenização do capital que alteraram profundamente o padrão tradicional do fluxo de renda instalado por séculos na colônia brasileira. $\mathrm{O}$ novo padrão de acumulação era o resultado direto das reformas pombalinas que estimularam a diversificação da produção agropastoril na colônia, transformada em fornecedora de alimentos e matérias-primas industriais, sem abdicar dos tradicionais produtos tropicais de exportação, açúcar, cacau, mas que foram, gradativamente, desalojados de sua condição hegemônica secular. $\mathrm{O}$ algodão tornou-se o segundo produto na pauta de exportação com $24 \%$ do total exportado mensurado em valores, atrás apenas do açúcar com 36\%, açúcar este que, em 1690, respondia por $90 \%$ da mesma pauta de exportação. Além do algodão, ingressaram na pauta uma imensa variedade de produtos outros que somava, no total, 126 itens, listagem esta que meio século atrás não passava de 33 produtos. Produtos-chave, de alta relevância histórica, pois alimentavam a nascente indústria portuguesa; supriam as necessidades da emergente indústria têxtil francesa; e, socorriam a indústria inglesa em tempos emergenciais.

Era, a colônia brasileira, portanto, que criava as condições para o $s u$ perávit da balança comercial portuguesa em relação à inglesa. Realidade que levou as autoridades britânicas a especular sobre a possibilidade de controlar diretamente a colônia portuguesa na América, fato que, de um só golpe, anularia os superávits comerciais portugueses; reequilibraria a balança comercial com Portugal; ampliaria sua fonte de suprimento de algodão num momento de carência absoluta; abriria o mercado brasileiro para as manufaturas têxteis inglesas; travaria o desenvolvimento manufatureiro de Portugal, que poderia transformar-se num concorrente potencial, além de preservar cativo este mercado para as manufaturas britânicas; e, acima de tudo, bloquearia o crescimento da nascente indústria têxtil francesa que se alimentava da matéria-prima brasileira recebida através de Portugal, razões mais do que suficientes para a adoção de medidas urgentes e agressivas em defesa de seus interesses econômicos, fossem elas no plano diplomático ou militar.

Esta disposição para romper com o tradicional aliado não era apenas fruto das circunstâncias imediatas geradas pelo conflito internacional com a França ou do desenvolvimento manufatureiro de Portugal. Era também o fruto de uma transformação substancial que se operava na política mercantilista do Estado britânico, dirigida ao comércio exterior. Sobretudo no quese referia ao modo de proceder em relação aos seus interesses econô- 
micos ou, mais explicitamente, em relação à sua política colonialista. A experiência traumática prodigalizada pela revolução americana provocou uma revisão dos princípios mercantilistas ortodoxos que preconizavam o domínio direto das colônias, que até então regiam a política colonialista do Império Britânico. As novas concepções, calcadas nos princípios do imperialismo do comércio livre, propunham o domínio informal das economias periféricas (Cain e Hopkins, 1980, pp. 463-490), domínios dos impérios concorrentes que precisavam ser "libertadas" de sua condição colonial. Sua primeira ação nesse sentido foi o estímulo desabrido às operações de contrabando perpetradas nos territórios coloniais. Uma forma indireta de subverter o monopólio, quebrar o pacto colonial das metrópoles europeias aliadas sem romper formalmente com a soberania destes Estados sobre suas colônias, mantendo a aparente normalidade das relações, e, no limite, estimular movimentos separatistas nos Impérios coloniais considerados inimigos que redundassem na formação de Estados independentes, organismos estes que, inevitavelmente, cairiam na órbita de influência do novo imperialismo britânico.

É a era do gentlemanly capitalism de Cain e Hopkins (1993, pp. 125137). Da simbiose social poderosa entre homens endinheirados da City, banqueiros e comerciantes focados na obtenção de lucro, mas bem aceitos pela aristocracia com os quais se fundiam. Eram ao mesmo tempo gentlemen e capitalistas, inclusão original que favorecia tanto a mudança quanto a estabilidade por agregarem privilégios políticos e diferenciação cultural. Segmento social que não almejava identificar-se diretamente com o mundo da indústria, das máquinas, das manufaturas ou dos empresários industriais. Nem mesmo com as colônias no velho estilo, mas com as finanças ultramarinas em escala global, voltados à moldagem de uma economia que dependia substancialmente das conexões internacionais e imperiais, que lhes garantiriam a preservação de uma condição distinguida de classe, a um só tempo capitalista e aristocrática, dotada de um singular life style.

Este é o cenário através do qual podemos entender a intensificação brutal das ações de contrabando britânico das costas brasileiras a partir de 1791, exatamente o ano em que se inicia a segunda inversão na balança de comércio anglo-portuguesa. Registra-se, neste ano, o aumento vertiginoso do número de navios estrangeiros entrados na barra do Rio de Janeiro. Foram 70 as embarcações estrangeiras -majoritariamente inglesas- entradas no porto no ano de 1800, exatamente o mesmo número de entradas registradas em 1808, ano da abertura dos portos, conforme se constata na tabela elaborada por Ernest Pijning (1997, p. 82). Equivale dizer que, sendo o comércio entre Portugal e suas colônias monopolizado, a presença destes navios significava prática insidiosa de contrabando, reveladora, de um lado, da agressividade inglesa e, do outro, da conivência das 
autoridades coloniais com a presença dos contrabandistas britânicos que traficavam abertamente na barra do porto do Rio de Janeiro e adjacências, mercadorias inglesas que eram trocadas por ouro em pó, em barras e, até mesmo, por mercadorias, a exemplo do cacau, práticas que, em última instância, comprovam que os portos brasileiros estavam de fato franqueados aos ingleses em 1800, muito antes de sua abertura formal em 1808.

A pressão via contrabando era uma medida paliativa. Era a expressão inicial do novo imperialismo britânico que se revelaria muito mais ousado no momento seguinte, quando não hesita em planejar a tomada militar da colônia. De fato, entre 1806 foi elaborado um plano secreto voltado à preparação de uma esquadra britânica que deveria desembarcar 10000 infantes no Rio de Janeiro, instruídos para tomarem de surpresa a cidade e para, no caso de resistência, dirigir-se a alvos alternativos: Salvador, na Bahia, ou Santa Catarina, no litoral sul. O teor do documento, que se segue, recentemente descoberto (Wilcken, 2005), explicita a essência da política externa inglesa neste contexto histórico particular:

Dez mil, incluindo infantaria, devem prosseguir [...] diretamente para o Rio de Janeiro. A intenção de se dirigir àquele lugar não deve ser divulgada. A expedição deverá adentrar a baía e as tropas desembarcadas com a menor impressão de hostilidade possível, de modo a tomar posse do lugar, de surpresa. Esta força não deverá tentar penetrar no interior do país, mas esperar no Rio de Janeiro até que a expedição de Lisboa chegue ao Brasil [...]. Poderá ser prudente fazer os habitantes entenderem que uma segunda expedição era esperada, acompanhada do Governo português; contudo, se eles se determinarem a se opor à nossa entrada, será aconselhável que nossa expedição deverá prosseguir para a ilha de santa Catarina, deixando a tomada do Rio de Janeiro para uma futura oportunidade. ${ }^{1}$

Planos que não foram postos em execução por mera circunstância. Porque nesse momento intensificava-se a pressão francesa nas fronteiras entre Portugal e Espanha, evento que dava aos ingleses a certeza de que o Regente português, D. João, acabaria por ceder à pressão diplomática britânica e acabaria por se refugiar no Brasil. Foi esta certeza que levou o governo britânico a redirecionar a esquadra previamente destina ao Brasil para atacar Buenos Aires e Montevidéu, entre os meses de junho de 1806 e agosto de 1807. Nos fins de 1807, em 22 de outubro, quando a invasão de Portugal pelas tropas napoleônicas tornou-se iminente, os ingleses negociaram com os portugueses a Convenção Secreta de Londres, assinada pelos plenipotenciários George Canning e Domingos de Souza Coutinho,

${ }^{1}$ Documentos pertencentes ao Dropmore Papers, v. CCCXXXI, add. 59285, before June, 25th. 1806. The British Library Manuscripts Room, Londres. 
portanto, apenas 36 dias antes do embarque da família real para o Brasil. Convenção esta que delineava previamente o futuro histórico do Império português, do Reino e das colônias, uma espécie de enredo antecipado do que viria a acontecer, o futuro previsto no passado: a viagem da Corte sob "proteção" inglesa; a abertura dos portos brasileiros às "nações amigas"; a assinatura dos Tratados de Comércio, Aliança e Amizade com a Inglaterra; a ocupação da Ilha da Madeira por tropas inglesas; a garantia de um porto privativo em Santa Catarina ou local equivalente na costa brasileira, a partir do qual os ingleses poderiam operar no Rio da Prata. Em suma, um exemplo explícito de unilateralidade, pois a única vantagem oferecida pelos ingleses aos portugueses resumia-se, naquele momento, a uma promessa: a de que a dinastia dos Bragança continuaria a reinar em Portugal, assim que os franceses fossem expulsos.

\section{ARRANQUE DA INDUSTRIALIZAÇÃO BRITÂNICA}

A inversão da balança comercial em relação a Portugal após a abertura dos portos é a prova mais contundente da eficácia do imperialismo do comércio livre. Os déficits que ainda perduraram no quinquênio 1796 a 1800, transformaram-se em superávits polpudos entre 1801 e 1810, e absolutamente fantásticos no quinquênio 1811-1815, quando se aproximaram da casa dos três milhões de libras esterlinas (Arruda, 2008, p. 82).

É preciso observar que os índices ali consignados referem-se ao movimento de importação e exportação entre a Inglaterra e Portugal. Valores que, até a abertura dos portos, incluíam o comércio indireto da Inglaterra com o Brasil, pois que seus produtos lá chegavam através de Portugal. Equivale dizer, o comércio direto da Inglaterra com o Brasil estabelecido após a abertura dos portos não pode ser mensurado a partir da Balança de Comércio portuguesa, nem a partir de indicadores estatísticos coloniais, porque eles não existiam no período entre 1808 e 1821, mas unicamente a partir das fontes externas, no caso os Customs ingleses, ${ }^{2}$ que fazem o papel das Balanças de Comércio portuguesas no que se refere ao comércio com a Inglaterra. Nestes termos, o comércio exterior do Brasil neste período exige uma composição de índices oriundos das séries portuguesas e dos demais países envolvidos no comércio brasileiro, tarefa por nós parcialmente realizada ao pesquisar os referidos Customs ingleses e nos valermos da contribuição de outros pesquisadores, a exemplo de Javier Cuenca Esteban.

\footnotetext{
${ }^{2}$ Documentos pertencentes ao National Archives, Public Record Office, Customs 4 to 16, Exports and Imports from Great Britain by Countries, 1808-1821, Londres.
} 
Isto significa que os dados que compõem a tabela 1 abaixo (Arruda, 2008 , p. 63) relativos às exportações brasileiras para a Inglaterra põem em evidencia o algodão em rama, cujos valores superam produtos tradicionais da exportação colonial, a exemplo do açúcar e dos couros, além de exibir um produto novo, mas já responsável por valores significativos, o café, destinado, como bem sabemos a tornar-se o produto rei das exportações brasileiras no século XIX. Já a tabela 2 de exportação de algodão abaixo (Arruda, 2008, p. 65), igualmente referida ao algodão, mas que avalia sua participação porcentual no montante total das exportações destinadas à Inglaterra, demonstra que o mesmo contribuía com $65.8 \%$ do total em valores oficiais, sendo que em anos excepcionais, como ocorreu em 1812, exatamente no ápice dos bloqueios e contra bloqueios navais que travaram as trocas internacionais, o algodão era responsável por $83.60 \%$ da receita total gerada pela exportação para a Inglaterra. Mesmo depois de 1815 , quando as relações internacionais se acalmaram e o mercado algodoeiro tendeu à estabilização, os índices da participação da fibra permaneceram em patamares elevados, acima de 70\%, o que nos leva a concluir que o algodão era inquestionavelmente o alvo preferencial das operações comerciais inglesas no mercado brasileiro.

A tabela 3 referente às exportações britânicas para o Brasil (Arruda, 2008 , p. 58) é a contra face da tabela 2 , pois espelha as importações coloniais brasileiras da Inglaterra. Revela os principais produtos de exportação da indústria têxtil britânica destinada ao mercado brasileiro: algodão, linho e lã. Demonstra que o Brasil era, sobretudo, um mercado para tecidos de algodão, seguindo-se a uma distância considerável em termos de valor os tecidos e manufaturas em lã e, numa escala residual, os produtos derivados do linho. A comparação entre os valores globais obtidos pela exportação mensurada em libra, a partir dos registros oficiais, explicita a hegemonia do algodão que soma $66.30 \%$ dos valores pagos à Inglaterra pelo mercado brasileiro, valores extremamente elevados que chegam a superar a casa dos dois milhões de esterlinos em determinados anos, muito acima dos valores recebidos dos ingleses pela exportação da matéria-prima em rama, fazendo do comércio britânico o principal responsável pelo déficit permanente da Balança de Comércio brasileira após a abertura dos portos, levemente compensada pelos superávits alcançados no comércio com Portugal.

Esta é uma prova insofismável da importância estratégica que o algodão havia adquirido para a Inglaterra no contexto da revolução industrial e dos tempos convulsionados que o país atravessava na viragem do século XVIII para o XIX. É uma prova também da eficiência da política executada pela diplomacia inglesa com base nos princípios do imperialismo do comércio livre, pois a Inglaterra, sem dominar diretamente o Brasil, as- 


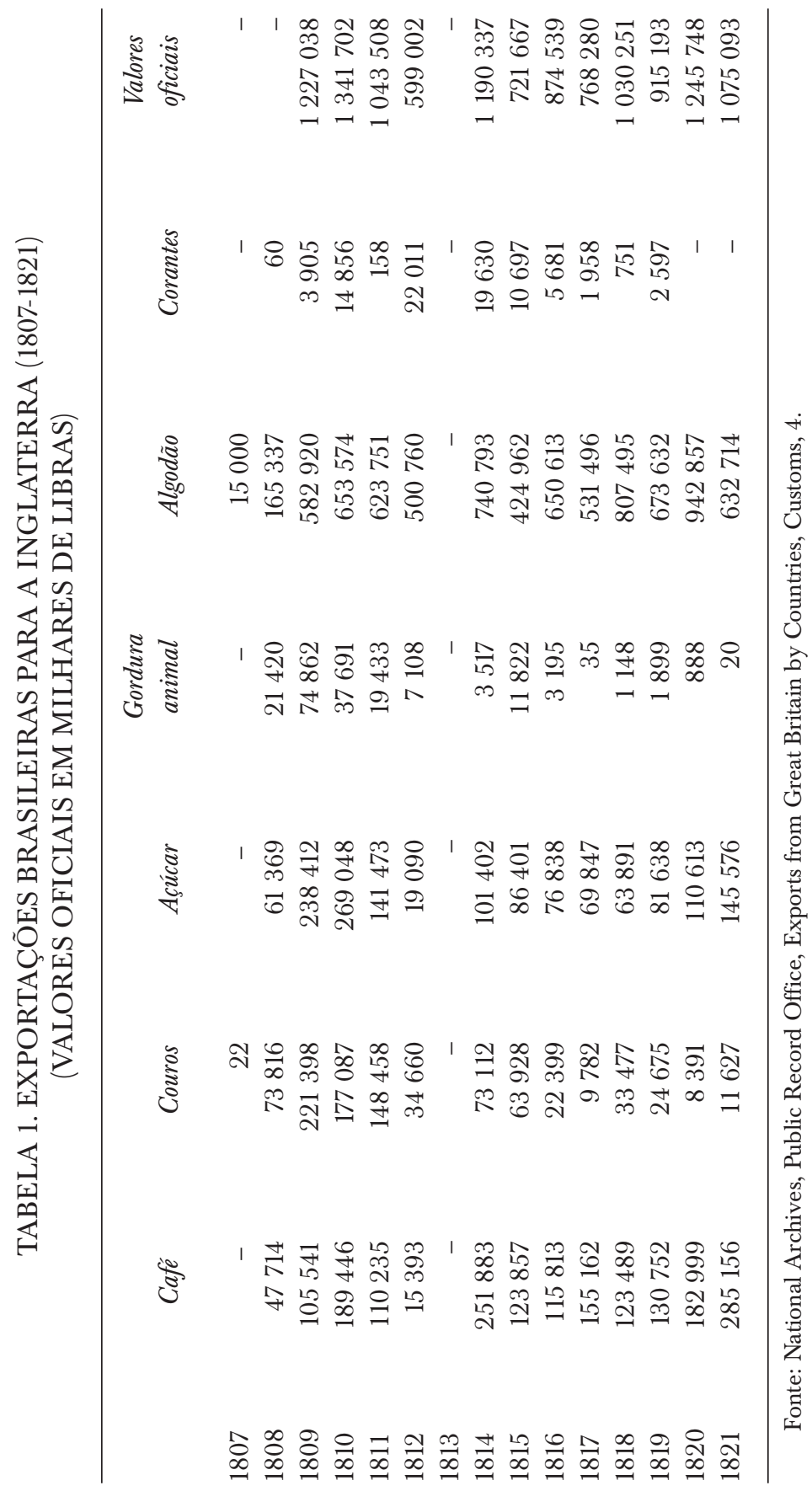


TABELA 2. EXPORTAÇÃO DE ALGODÃO EM RAMA PARA A INGLATERRA EM RELAÇÃO ÀS EXPORTAÇÕES GLOBAIS

\begin{tabular}{|c|c|c|c|}
\hline & Total oficial & Algodão & Porcentagem \\
\hline 1807 & - & 15000 & - \\
\hline 1808 & - & 165337000 & - \\
\hline 1809 & 1227038000 & 582920000 & 47.51 \\
\hline 1810 & 1341702000 & 653574000 & 48.71 \\
\hline 1811 & 1083194000 & 623751000 & 57.58 \\
\hline 1812 & 599022000 & 500760000 & 83.60 \\
\hline 1813 & - & - & - \\
\hline 1814 & 1190337000 & 740793000 & 62.23 \\
\hline 1815 & 721667000 & 424962000 & 58.89 \\
\hline 1816 & 869539000 & 650613000 & 74.82 \\
\hline 1817 & 768280000 & 531496000 & 69.18 \\
\hline 1818 & 1030251000 & 807495000 & 78.38 \\
\hline 1819 & 915193000 & 673632000 & 73.61 \\
\hline 1820 & 1245748000 & 942857000 & 75.69 \\
\hline \multirow[t]{2}{*}{1821} & 1075093000 & 632714000 & 58.85 \\
\hline & & Média & 65.8 \\
\hline
\end{tabular}

Fonte: National Archives, Public Record Office, Exports from Great Britain by Countries, Customs, 4 .

sumira o controle do seu mercado por vias indiretas, por via do imperialismo informal, tornando-se uma colônia exportadora de matérias-primas e consumidora de produtos transformados, uma clara antecipação dos mecanismos clássicos do neocolonialismo que preponderaria nas relações metrópole-colônia no decurso do século XIX, certamente benéfico para os britânicos, mas extremamente ruinosos para as manufaturas portuguesas.

\section{ENTRAVES À INDUSTRIALIZAÇÃO PORTUGUESA}

Na segunda metade do século XVIII e, muito especialmente, em sua quadra final, as manufaturas portuguesas atingiram um nível significativo de desenvolvimento. Suas raízes remontam à política de industrialização estabelecida por Pombal, assentadas em bases muito mais sólidas do que as experiências fugazes do século anterior. Resultam de um projeto integrado que envolvia a um só tempo a indústria, a agricultura e o circuito 
TABELA 3. EXPORTAÇÕES BRITÂNICAS PARA O BRASIL (IMPORTAÇÕES BRASILEIRAS DA INGLATERRA), 1808-1821 (MILHARES DE LIBRAS)

\begin{tabular}{|c|c|c|c|c|c|}
\hline & Algodão & Linho & Tecidos de lã & $\begin{array}{c}\text { Reexportações } \\
\text { britânicas } \\
\text { para o Brasil }\end{array}$ & Total \\
\hline 1808 & 1413000 & 47000 & 480000 & 172000 & 2112000 \\
\hline 1809 & - & - & - & 143000 & - \\
\hline 1810 & - & - & - & 332000 & - \\
\hline 1811 & - & - & - & 136000 & - \\
\hline 1812 & 1557000 & 23800 & 223000 & 86000 & 1889800 \\
\hline 1813 & - & - & - & - & - \\
\hline 1814 & 1081000 & 44300 & 205000 & 93000 & 1423300 \\
\hline 1815 & 1200000 & 33100 & 213000 & 40000 & 1486100 \\
\hline 1816 & 1225000 & 110000 & 237000 & 20000 & 1592000 \\
\hline 1817 & 1547000 & 153000 & 279000 & 16000 & 1995000 \\
\hline 1818 & 2121000 & 194000 & 379000 & 32000 & 2726000 \\
\hline 1819 & 1058000 & 152000 & 261000 & 32000 & 1503000 \\
\hline 1820 & 1384000 & 201000 & 240000 & 46000 & 1871000 \\
\hline 1821 & 1424000 & 152000 & 241000 & 22000 & 1839000 \\
\hline
\end{tabular}

Fonte: National Archives, Public Record Office, Exports from Great Britain by Countries, Customs, 4 .

comercial, interpretação essa que diverge dos diagnósticos clássicos sobre a política pombalina, a exemplo da esposada por Jorge Borges de Macedo (1982, p. 26). O estímulo à agricultura tornou-se o esteio da nova política econômica, com resultados surpreendentes no Brasil. Produtos para a reexportação do Reino (açúcar, cacau, tabaco), alimentos para a população metropolitana (arroz) e matérias-primas para as manufaturas (algodão, couros), enlaçam agricultura e indústria, tornando a caminhada rumo à industrialização uma possibilidade concreta. A criação de companhias de comércio privilegiadas fechava o circuito, porque aproximava os espaços coloniais e metropolitano, redesenhava uma nova configuração para o Império Luso-Brasileiro. Não se tratavam, pois, de medidas conjunturais. Eram ações conscientes e objetivas que tornavam a economia metropolitana ainda mais dependente do espaço colonial.

A diversificação da produção agrícola na colônia é um fato (Arruda, 1980). Se sua exportação para a metrópole produzia um déficit em favor da 
colônia, sua reexportação para outros países garantia saldos expressivos para Portugal (Novais, 1973, pp. 59-75), saldos traduzidos em recursos monetários, créditos, letras de câmbio, pagamento de importações e, por certo, investimentos no parque manufatureiro. Recursos tão valiosos que, nas décadas finais do século XVIII, possibilitaram o superávit da balança comercial portuguesa em relação à inglesa, como já referimos anteriormente. Mais importante ainda foi o fato de que parte substancial das matérias-primas remetidas para Portugal, especialmente o algodão em rama, passaram a ser transformadas pelas tecelagens portuguesas, provocando um surto industrial respaldado, do lado do consumo, pela própria colônia, um mercado seguro por ser monopolizado. Mercado perfeito para quem, como Portugal, encontrava-se nos estágios preliminares da industrialização.

As importações de produtos das fábricas portuguesas realizada pela colônia brasileira entre 1796 e 1821 são a prova mais consistente de que as fábricas portuguesas não eram mera fantasia, como querem alguns historiadores portugueses, e que, mantendo-se o ritmo do crescimento alcançado, poderia transformar-se num processo irreversível de industrialização. As matérias-primas que rumavam para Portugal retornavam transformadas com valor agregado, acentuando-se a transferência de renda para a metrópole. As tabelas 4 e 5, que se seguem, demonstram que em todas as regiões brasileiras os produtos das fábricas portuguesas rivalizavam com os similares procedentes das nações estrangeiras, adquiridos por Portugal para abastecer a colônia. A representação percentual desse movimento demonstra que lanifícios, linifícios, sedas, metais e vários gêneros, produtos manufaturados procedentes dos países mais avançados, a exemplo da Inglaterra, representam $35.02 \%$ do total das importações coloniais, considerados na média de todas as regiões brasileiras. Mercadorias que são, ao mesmo tempo, reexportações portuguesas endereçadas à colônia, a saber, para o Rio de Janeiro, Bahia, Pernambuco, Maranhão e Pará, exclusive Paraíba e, desses portos redistribuídas para outras regiões brasileiras. Já os produtos das fábricas portuguesas correspondem a $28.22 \%$ do total das importações coloniais, na média das mesmas regiões citadas. Índices extremamente significativos, indicativos de que, até a abertura dos portos, uma parcela expressiva de todas as manufaturas importadas era produzida nas fábricas portuguesas, e que seu valor correspondia a quase $30 \%$ dos recursos despendidos para pagar a totalidade das importações coloniais, cabendo aos similares estrangeiros um pouco mais de 30\%. Prova inconteste da existência de um processo de crescimento industrial em Portugal e, sobretudo, da importância vital do mercado colonial para sustentá-lo.

Se aceitarmos a ponderação de Valentim Alexandre (1993, p. 30), segundo a qual um número não quantificável de produtos que integram as listas de mercadorias importadas pela colônia oriundas da Inglaterra eram, 


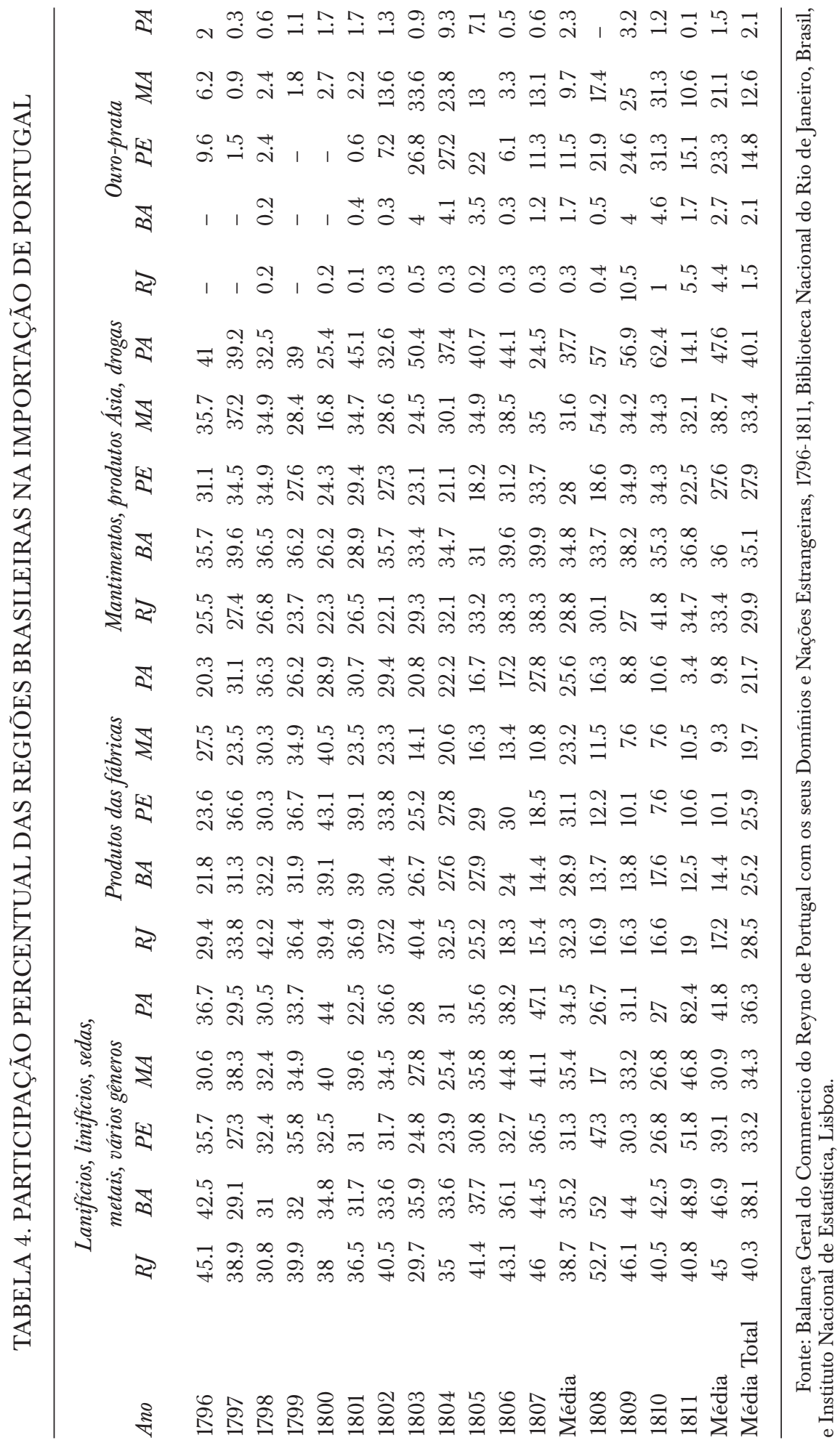




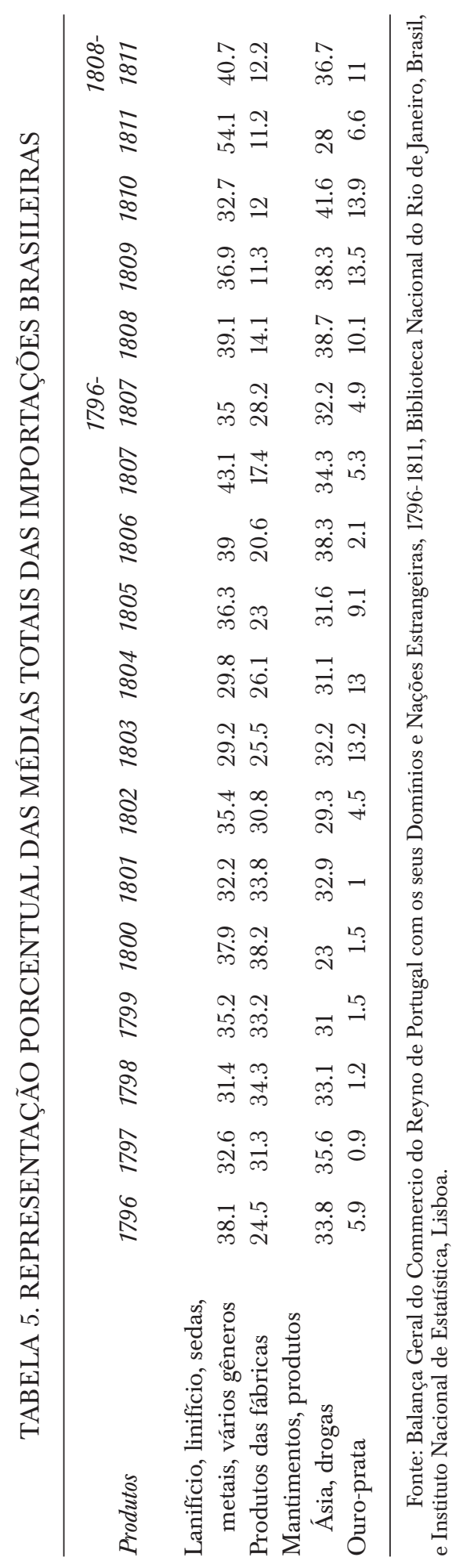


na verdade, produzidas em Portugal, os números relativos às fábricas portuguesas seriam ainda mais expressivos. Se somarmos as importações de produtos industrializados, portugueses ou estrangeiros, a porcentagem atinge $63.2 \%$, demonstrando a elasticidade do mercado consumidor da colônia neste momento, convertido num clássico buyers market. As demais rubricas, Mantimentos, Produtos da Ásia, Drogas e Vários Gêneros somavam 32.2\%, dentre os quais apenas Mantimentos e Produtos da Ásia tinham maior expressão. Note-se que os gastos com alimentos evidenciam poder de consumo, porque se destinavam, sobretudo, aos ditos homens bons, livres, com poder aquisitivo mais elevado em relação à massa escrava da população.

Se isolarmos algumas regiões brasileiras em anos determinados, o potencial de crescimento das manufaturas portuguesas refletidos no consumo colonial fica ainda mais expressivo. No Rio de Janeiro, no ano de 1798, as importações das fábricas portuguesas bateram as importações oriundas de outros países por $42.2 \%$ a $30.8 \%$; em 1803 , por $40.4 \%$ a $29.7 \%$. Se na Bahia a importação de manufaturados de outras nações vence sistematicamente os produtos oriundos da indústria portuguesa, nos anos 1800 e 1801 os percentuais tornam-se favoráveis às mercadorias portuguesas. Em Pernambuco, pelo contrário, constata-se nítida preferência pelos produtos das fábricas do Reino confirmada nos percentuais obtidos em 1797 e nos anos 1800-1804, com incidências excepcionais, como se deu em 1800, quando Pernambuco consumiu apenas 32.5\% de manufaturados estrangeiros contra 43.1\% da produção oriunda do Reino, como se pode depreender da análise da tabela 4 . Nela, são comparadas as importações procedentes das nações estrangeiras reexportadas para a colônia, os produtos das fábricas portuguesas, os mantimentos, os produtos da Ásia e as Drogas, além do gráfico sobre as importações de ouro e prata, remessas monetárias compensatórias destinadas ao pagamento das exportações coloniais, ou sob a forma de peças de consumo suntuário.

O perfil das relações econômicas implícitas nessas constatações revela um novo padrão de relacionamento, um patamar diferenciado de acumulação que evidencia, por sua vez, um novo tipo de colonização, cujos traços mais significativos somente se expressariam com toda nitidez no contexto do neocolonialismo afro-asiático na segunda metade do século XIX, como já apontamos. A colônia brasileira transformara-se, destarte, no Prometeu que poderia desacorrentar a indústria portuguesa, não fora pela abertura dos portos brasileiros em 1808, cujo impacto se evidencia nas tabelas acima, pois é flagrante o recuo das entradas de manufaturas portuguesas em favor das estrangeiras, que, naquela conjuntura específica, significavam manufaturas inglesas. A importância deste fato é inquestionável. Representou o golpe definitivo nas pretensões industrializantes de 
Portugal. Interrompeu um processo a duras penas retomado, depois da experiência frustrada do século XVII, e que ainda não se consolidara suficientemente para ser capaz de resistir à perda do mercado privilegiado da colônia e a vanguarda tecnológica da Inglaterra.

\section{ASFIXIA DA INDÚSTRIA TÊXTIL FRANCESA}

Se em Portugal a abertura dos portos brasileiros impôs entraves à continuidade do crescimento industrial, o impacto sobre as novas indústrias francesas foi devastador.

Entre Portugal e Brasil, os vínculos políticos continuavam a ser muito fortes apesar de não haver mais a exclusividade econômica. O Brasil continuava a ser parte do império português, promovido à condição de Reino Unido. A rede comercial entre negociantes portugueses e brasileiros, por séculos instalada, continuava a operar. A forte corrente emigratória portuguesa não sofreu qualquer tipo de constrição. Equivale dizer, as exportações de matérias-primas continuavam a alimentar as manufaturas portuguesas e estas continuavam a fluir para a colônia, não mais, porém, com a mesma exclusividade ou intensidade. Mantiveram-se num patamar rebaixado e até mesmo voltaram a crescer depois que o mercado europeu se estabilizou e os ingleses recuperaram mercados tradicionais, sem jamais atingir o patamar alcançado antes da abertura dos portos. Mas isto não se deu com a França após a abertura dos portos brasileiros, ela que fora de longe o principal mercado para os produtos brasileiros, especialmente para o algodão.

O poderio marítimo dos ingleses teve efeitos contraditórios sobre o crescimento econômico da França. $\mathrm{O}$ fechamento dos portos europeus durante o bloqueio continental favoreceu o deslocamento das indústrias francesas em direção ao centro da Europa, movimento que representou a interiorização continental da economia francesa por deslocar-se rumo ao vale do Reno, afastando-se das regiões portuárias que, em consequência, entraram em declínio. Seja por conta das incursões inglesas, seja pela vontade de avançar sobre o mercado europeu (Viennet, 1947, pp. 43 e segs.). Dessa forma, podemos afirmar "que o enfraquecimento relativo, mas real das indústrias tradicionais, foi compensado pelo surgimento de indústrias novas que, no decurso da revolução, anunciavam um novo 'reino industrial': os têxteis de algodão, totalmente independentes da agricultura nacional e ligados a importações massivas e crescentes de matérias-primas" (Leon, 1974, p. 419).

Era essa a grande inovação industrial. Os têxteis de algodão. $\mathrm{O}$ verdadeiro motor do crescimento econômico da França naquele momento. 
Única aos olhos dos contemporâneos que a consideravam "fenomenal", por ser capaz de desenvolver-se de forma inesperada num contexto internacional agressivo de embargos e bloqueios e, ao mesmo tempo, atender ao gosto dos consumidores, pois os franceses haviam aderido à moda dos tecidos de algodão por influência das importações asiáticas, sobretudo indianas. O elã industrialista era imenso, motivando Napoleão a condecorar o industrial Oberkampf, pioneiro na indústria algodoeira na França, oportunidade na qual proferiu a frase que traduz a importância estratégica desta indústria na batalha travada em duas frentes contra os ingleses: "Nós estamos ambos conduzindo a guerra contra os britânicos, mas a sua guerra é a melhor" (Heckscher, 1964, p. 272). Projeto econômico exitoso enquanto o projeto político-militar foi bem sucedido, consumando-se o arranque da indústria têxtil francesa fundamentada nas manufaturas de algodão. Um aparato instrumental com tendência a evoluir tecnicamente, sobretudo em momentos de alta de preços como aquele que se vivenciava em função da conjuntura excepcional, que acabava por estimular a produção em escala ampliada e, por via de consequência, a redução dos custos, fazendo crescer a margem de lucros e as possibilidades de reinvestimento.

De fato, a manutenção do fluxo contínuo de algodão bruto importado, e a consequente manutenção dos baixos preços da matéria-prima, era a condição sine qua non para garantir minimamente a competitividade da nascente indústria francesa em relação à inglesa já instalada e, até mesmo, em relação a centros manufatureiros de longa tradição existentes na Europa, como era o caso de Hamburgo. Quando, em 1807, o primeiro sinal de forte contração na entrada do insumo vital se anunciou, seus preços registram altas brutais: de 127\% no algodão cru vindo do Oriente Próximo; de $134 \%$ no algodão de fibra longa originário de Pernambuco. Ato contínuo, indústrias de fiação fecharam suas portas e, somente na região de Troyes, 10000 trabalhadores foram reduzidos à miséria pelo desemprego, número expressivo de trabalhadores que demonstra o elevado grau de desenvolvimento alcançado pela indústria francesa. Em localidades onde o crescimento industrial tinha sido vertiginoso, como nos territórios de Mulhausen na Alta Lorena, e para os quais o abastecimento de matéria- prima era absolutamente imprescindível, a crise foi ainda mais devastadora (Heckscher, 1964, p. 271). Em 1810, a crise industrial transformou-se numa crise financeira com tendência a generalizar-se para o conjunto da economia. Os efeitos nefastos do bloqueio marítimo se faziam sentir em todos os níveis da vida nacional. Apesar de protegida pelas medidas governamentais desde os inícios, a expansão das novas indústrias têxteis defrontou-se com a barreira intransponível da escassez da matéria-prima essencial. 
Sem dúvida, as vicissitudes da grande indústria algodoeira francesa jaziam na perda de posição nos circuitos marítimos que a conectavam ao mundo das colônias. Os ingleses, vitoriosos em Trafalgar (Cannadine, 2006), controlavam quase metade da frota mercante mundial: exatos $42 \%$ (Maddison, 2001, p. 95). Sem a proteção militar adequada, os barcos mercantes franceses foram alijados do Atlântico; excluídos do Oceano Índico. Os portos continentais diretamente ligados a essas atividades tais como Bordeaux, Nantes, Le Havre, Marseille, entraram em declínio, abrindo mão de sua condição de portos internacionais para se converterem em pontos de escala na navegação de cabotagem nas costas francesas (Soboul, 1976). Regressão do poderio naval que reduziu drasticamente a área de atuação da marinha mercante e suas possibilidades de garantir o fluxo necessário de matérias-primas coloniais. Problema acusado por Napoleão, em 1809, quando afirmou que "seria melhor usar apenas lã, linho e seda, produtos de nosso próprio solo, e prescrever o algodão do continente para sempre, porque nós não temos colônias" (Heckscher, 1964, p. 277). Referência implícita à perda da colônia de Santo Domingo, no contexto da revolução francesa, que representara um duro golpe no império colonial francês.

Nestes termos, a pressão inglesa sobre Portugal, no sentido de forçar a transferência da família real portuguesa para o Brasil, significava mais do que a simples abertura dos portos brasileiros para seus produtos bloqueados no continente europeu. Significava a asfixia das novas indústrias têxteis francesas. A tabela 6 e o gráfico 1 , referentes à participação percentual dos principais compradores de produtos brasileiros através de Portugal, não deixam margem a dúvidas sobre a importância adquirida pela França no comércio colonial português. A partir de 1800 crescem as importações francesas do Brasil, superando gradativamente as importações italianas, inglesas e hamburguesas. A França, que recebia apenas $0.6 \%$ das exportações coloniais brasileiras em 1800, passou à liderança dos países importadores de insumos coloniais em 1804, quando absorveu 31.9\% do total. Posição de liderança que se amplia nos anos subsequentes chegando, em 1807 , a $38.8 \%$ de tudo que foi exportado pela colônia. Quase o dobro do segundo colocado, a Itália, com $20.6 \%$ e, certamente, mais do que o dobro dos tradicionais líderes no consumo de efeitos coloniais brasileiros: Hamburgo e Inglaterra, com aproximadamente $17 \%$ cada um.

O gráfico 1 explicita a hegemonia crescente da França na importação de efeitos coloniais brasileiros. Hamburgo preserva o primeiro lugar entre os importadores durante a maior parte do período considerado, mas sua tendência é declinante e, exatamente oposta à da França, que ao findar o período, em 1808, consumia $77.9 \%$ de todas as exportações coloniais direcionadas por Portugal às nações estrangeiras, uma hegemonia absoluta 


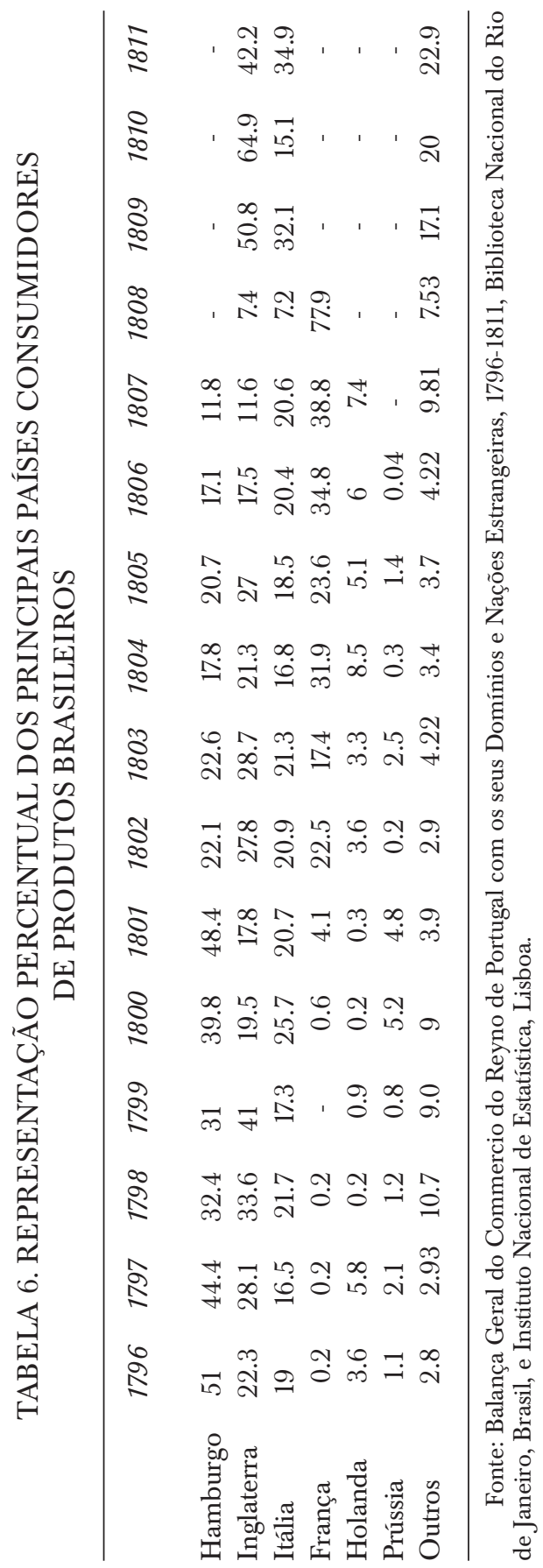




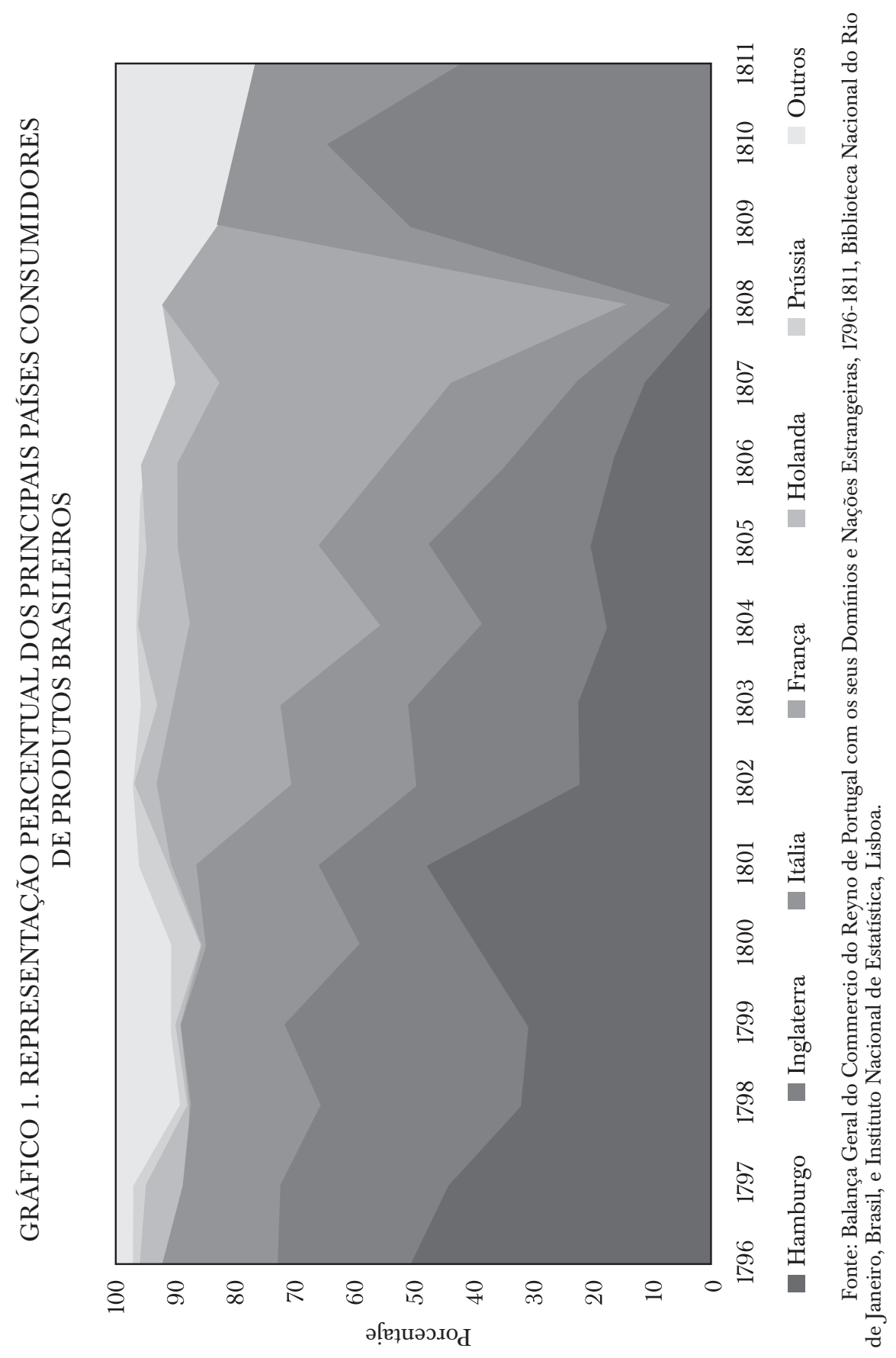


que desaparece por completo no ano seguinte à abertura dos portos. Na tabela 7 , referente às exportações de algodão brasileiro para as nações estrangeiras, comparando-se os índices da França e da Inglaterra, percebe-se que a condição inglesa de principal importadora da matéria-prima é superada pela França em 1804, quando esse país importou 323951 arrobas contra 228680 dos ingleses, importações francesas que se reduzem a 139316 arrobas em 1808 e a zero em 1809 (Arruda, 1980, pp. 300-307; 359 e ss).

Mais expressivos ainda são a tabela 8 e o gráfico 2, em que estão representados os valores em 1000 réis das importações feitas pela França, na qual estão agrupados os produtos que, somados, perfaziam $92.12 \%$ da totalidade das aquisições francesas. O resultado é extremamente revelador, pois, como já se previa, o algodão é o carro chefe, responsável por metade $(50.5 \%)$ de todas as aquisições; seguindo-se os couros em suas variedades (19.2\%); açúcar branco e mascavo (11.62\%); arroz, cacau e café $(7.2 \%)$ e tabaco (3.6\%). As matérias-primas industriais somam $69.7 \%$ e os alimentícios $18.82 \%$, comprovando a estreita relação entre a colônia brasileira e a industrialização francesa.

Estavam certos, portanto, os historiadores franceses quando apontam o ano de 1807 como marco crítico do desenvolvimento da indústria têxtil na França, relacionando-o à interrupção do fluxo do algodão americano atribuído ao Bloqueio Continental (Godechot, 1972; Crouzet, 1966). Não lhes escapa que, no fundo, o império marítimo criado pela Inglaterra estava no âmago das dificuldades, convicção que levou o historiador Pierre Leon a afirmar: "sobre todos os terrenos, através de todos os mercados mundiais, a concorrência dos têxteis ingleses e das quinquilharias de Albion tornavam-se cada vez mais duras para os produtos franceses, do Extremo Oriente à bacia do Mediterrâneo, da Europa aos países além do Atlântico" (Leon, 1974, p. 421), um mercado consumidor de 200 milhões de habitantes que os ingleses souberam arrebatar valendo-se das armas tarifárias, dos bloqueios e das ações militares diretas.

Mesmo atribuindo à revolução francesa a responsabilidade pela interrupção desta primeira fase da industrialização -apesar de todo clima liberal que havia criado-, Claude Fohlen (1973, pp. 19-20) reconhece a incapacidade dos governos revolucionários em proteger o império colonial por séculos preservado, a começar pela perda de Santo Domingo e dos escoadouros nos Estados Unidos, perdas estas que a tentativa de reservar o mercado europeu para a indústria francesa jamais foi capaz de compensar. Uma verdadeira catástrofe nacional produzida pela revolução francesa (Crouzet, 1966, p. 291), imediatamente refletida na balança comercial com as colônias cujo desempenho, que chegou a representar $18 \%$ do comércio 


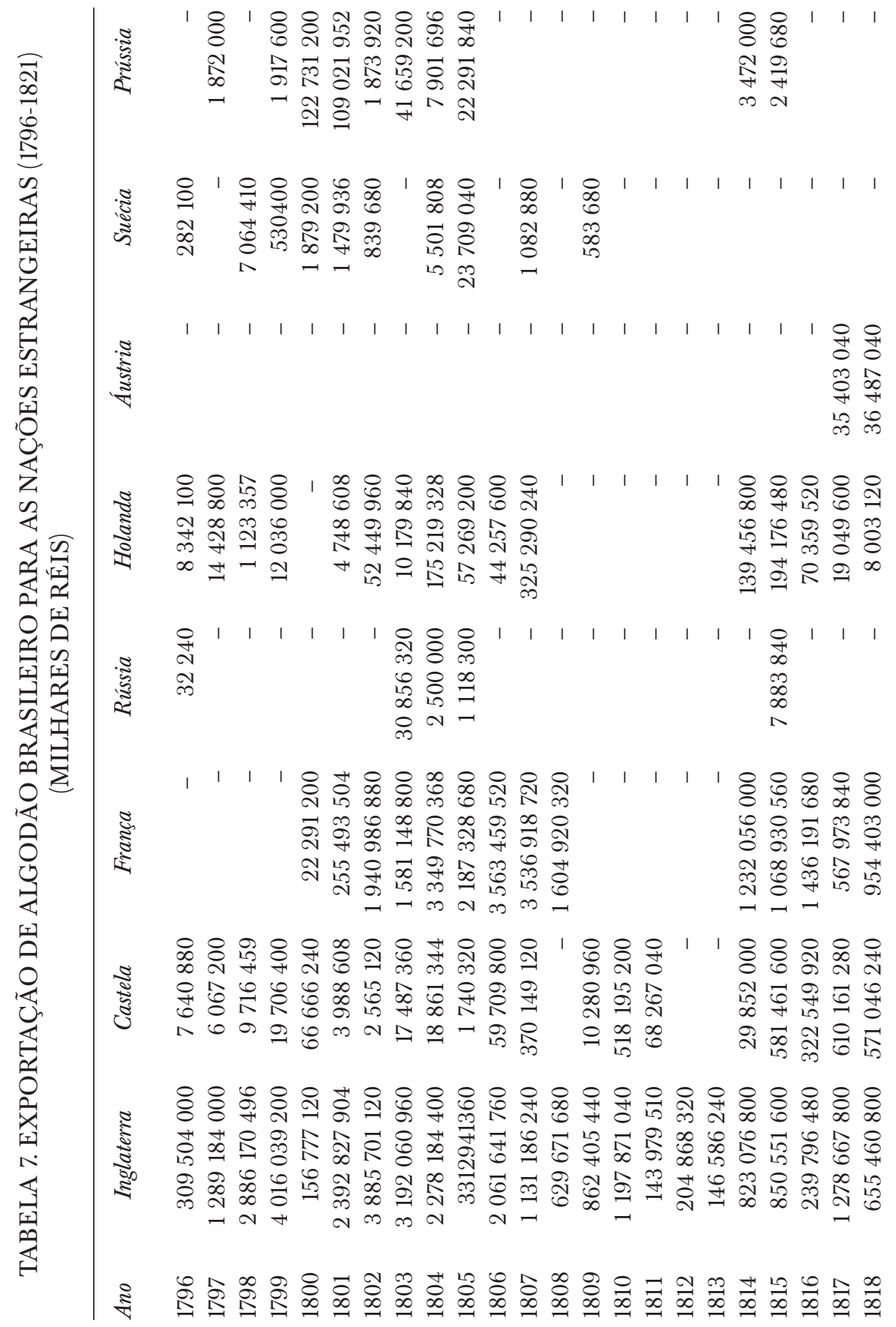


$\begin{array}{lll}1 & 1 & 1 \\ 0 & 1 & \infty \\ 0 & \infty \\ 0 & \infty \\ 0 & 1 \\ 0 & 0 \\ i & 0\end{array}$

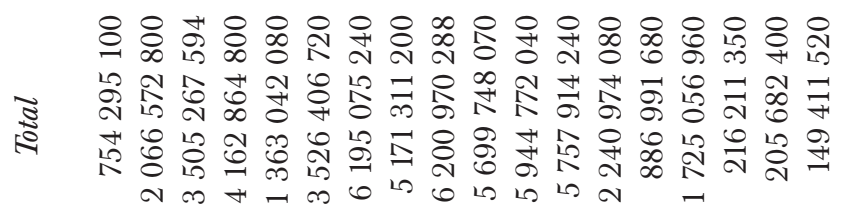

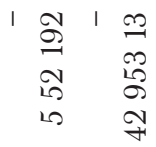

위웍 용 오

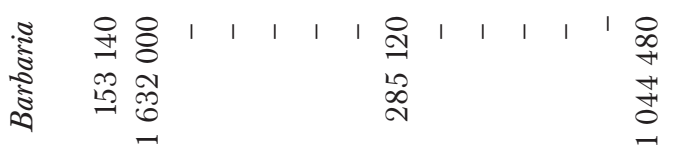

央络 원

б느늠

녕요요

\& से की

以ิ언

용

긍

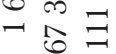

$\infty \infty \infty$

-

나용

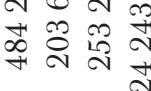

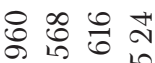

+1 80 今

12 10 ฟ

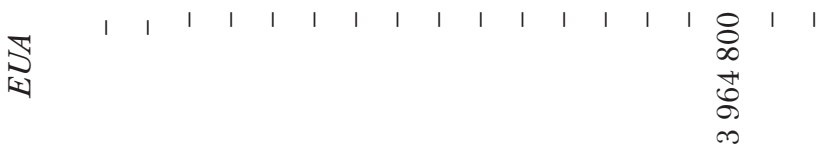

응웡 송 용

군슝항

ล 1080

तै

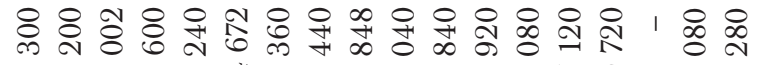

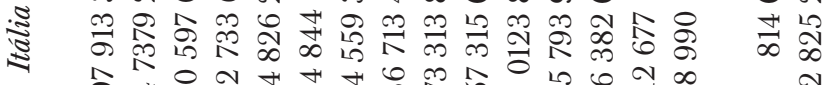

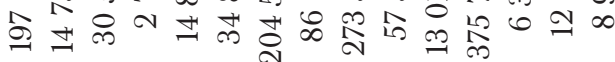

N

웅 융 \& \& \&

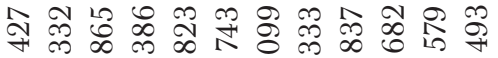

命

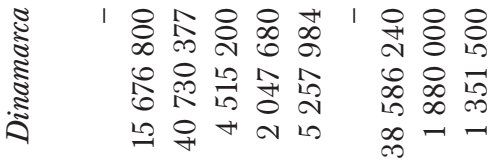

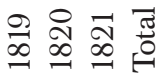

郘 


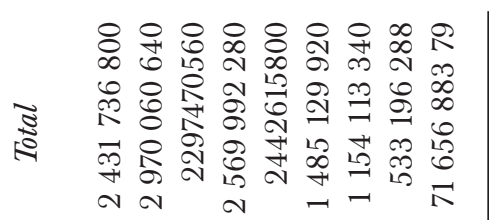

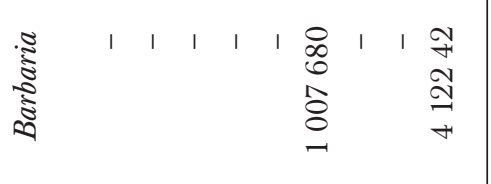




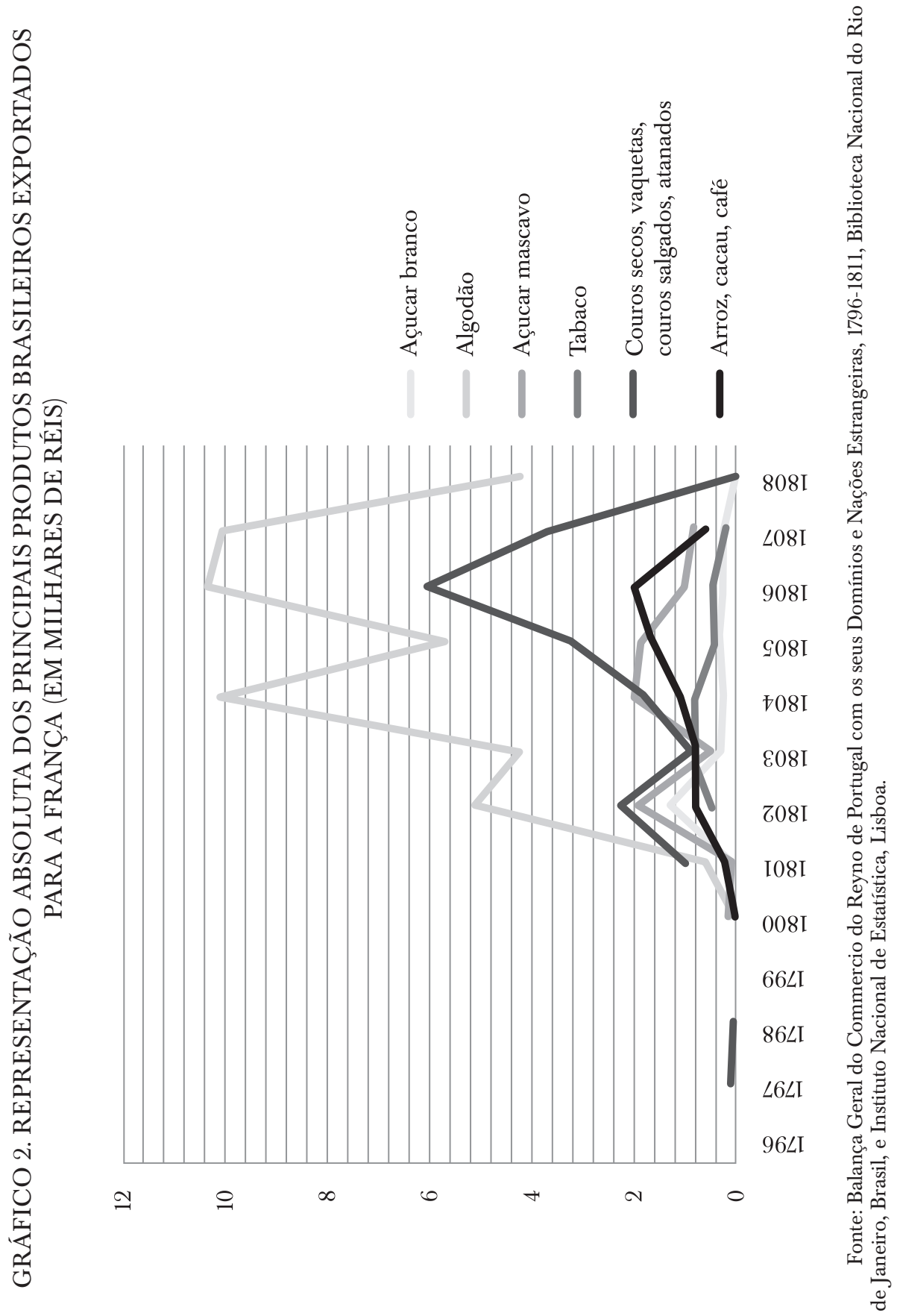




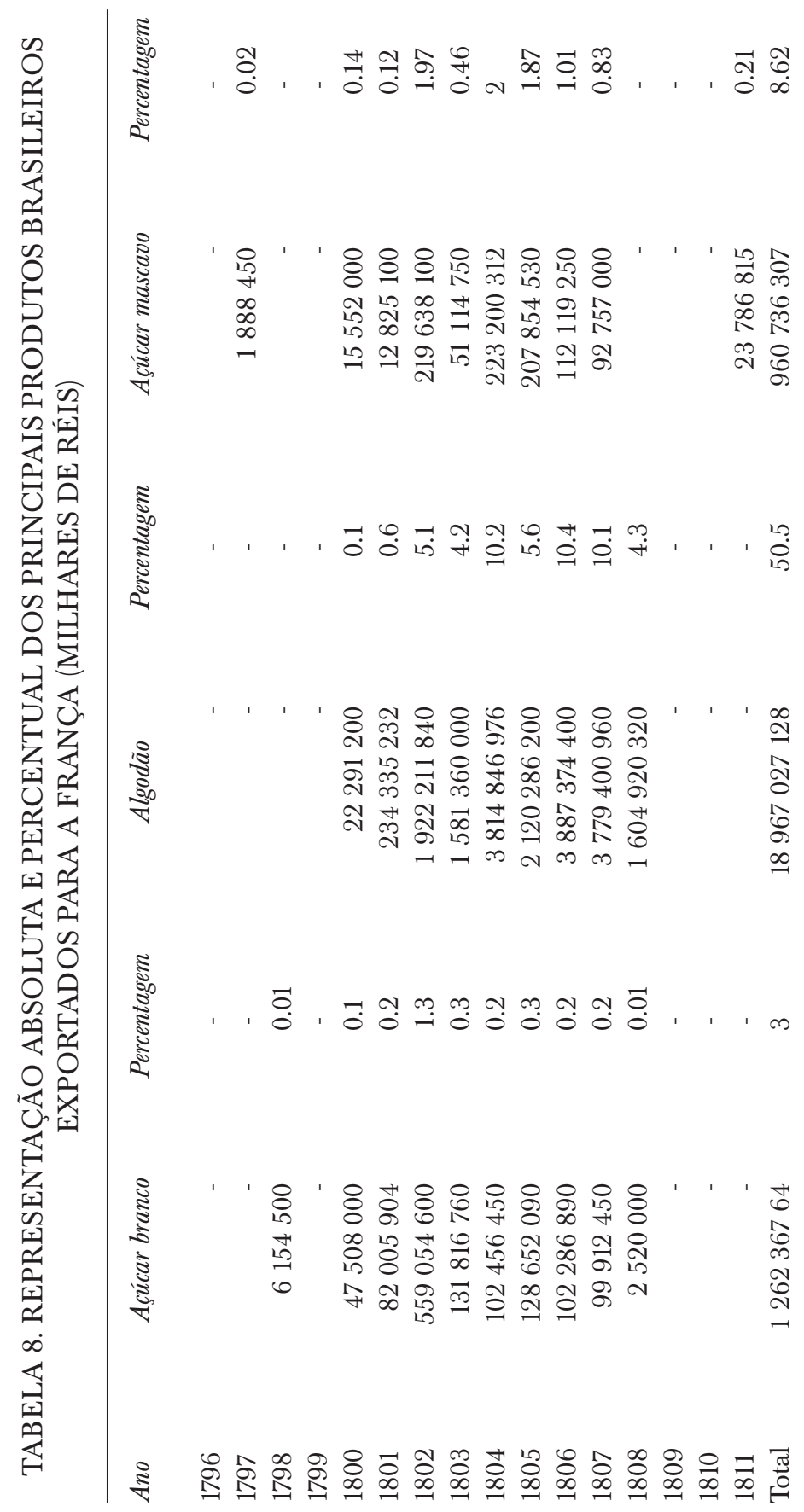




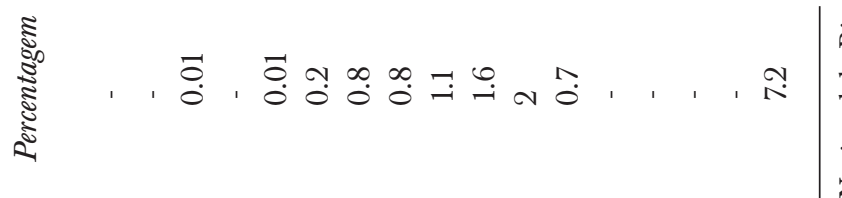

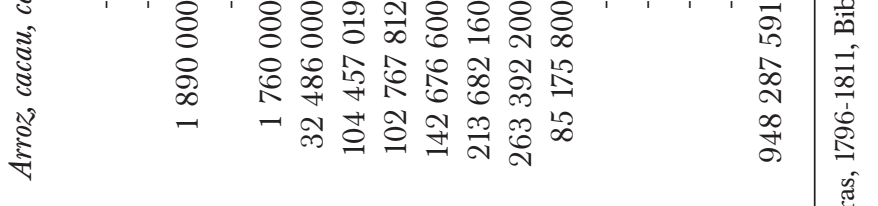

$$
\begin{aligned}
& \text { 幽 }
\end{aligned}
$$

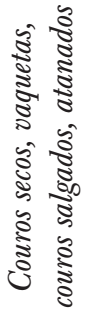

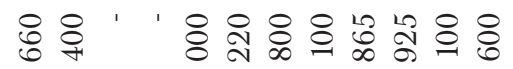

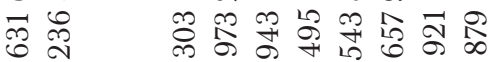

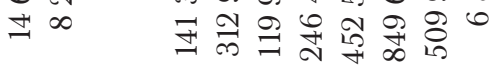

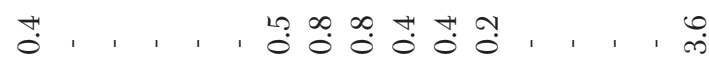

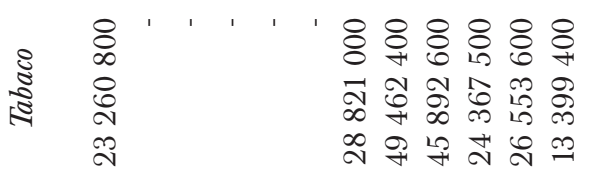

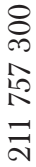

$$
\begin{aligned}
& \text { 苟 }
\end{aligned}
$$

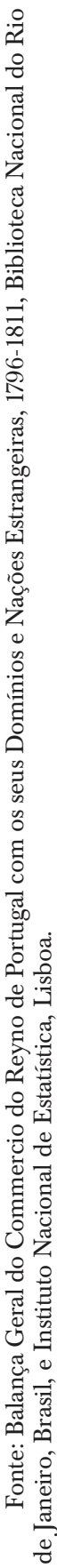


exterior da França no final do século XVIII, tornou-se residual (Romano, 1957, p. 1278).

\section{CONSIDERAÇÕES FINAIS}

O recurso à teorização é um instrumental indispensável para o conhecimento histórico. A análise crítica do período em questão demonstra os estreitos liames entre os países europeus envolvidos no processo de industrialização e o mundo das colônias. Nesse contexto, a trajetória histórica da distante colônia portuguesa no Atlântico Sul é ressignificada. Assume um papel destacado ao participar diretamente de um dos momentos de mais alta relevância para o desenvolvimento ulterior da civilização ocidental. Momento em que as colônias passam a jogar um papel central nas explicações para o arranque das industrializações, seja para contribuir com suas mercadorias e mercados consumidores para que as iniciativas empreendidas se consumassem no centro do sistema, seja para bloquear processos aos quais estavam ligadas por força de sua integração no mercado mundial.

O final do século XVIII assinala um momento crucial da história da colonização moderna, pois marca o início da vinculação direta das entidades coloniais ou nacionais com os países em fase acelerada de crescimento e desenvolvimento, sua primeira e verdadeira integração no mercado mundial (Arruda, 1986, p. 301). Seja dos Estados Unidos, cujo mercado foi decisivo no arranque industrial britânico (Price, 1979, p. 225); seja das ilhas açucareiras das Antilhas que lançaram os holandeses à liderança do segundo Sistema Atlântico (Emmer, 1998, p. 10); seja do Brasil, que propiciou a Portugal aproximar-se dos umbrais da industrialização e da nova forma de exploração colonial típica do neocolonialismo (Alexandre, 1993, p. 73); seja, no sentido negativo, dos obstáculos interpostos à França ao seu desenvolvimento pela perda de seu império colonial (O'Brien, 1998, p. 29).

Impensável, portanto, tratar as experiências de crescimento econômico nos países centrais de forma isolada, pois fazem parte, metrópoles e colônias, de um mesmo processo de acumulação do capital, que tende a transformar todos os espaços disponíveis em mercados, cada vez mais integrados pelo circuito do dinheiro (Arruda, 1991, p. 420), cujo fulcro de acumulação tende a ser carreado para os polos hegemônicos, criando a inevitável diferenciação entre os first commers e os late commers, originando uma categoria fantasmagórica, os nevercommers, eternos emergentes que talvez jamais viriam a cumprir seu destino e alcançar um lugar no rol dos países desenvolvidos. 
A corrente que perpassa o processo de industrialização em sua primeira fase, que convencionamos denominar a época da revolução industrial, ata de modo singular colônias e metrópoles, repondo em termos adensados suas experiências históricas específicas, que incluíram, ex ante ou ex post, um movimento político de natureza propriamente social e política, que nos relança ao debate sobre a dialética entre revoluções e crescimento econômico, entre política e economia. Sua apreensão exige uma prise globale. A revolução industrial inglesa não é um fenômeno isolado ou o fruto de uma especial dotação divina, como se os ingleses fossem criados para serem o homo sapiens da industrialização, insinuação feita por David Landes (1994, p. 224). Muito menos algo que, de um ponto de vista estritamente ontológico, simplesmente "não aconteceu", pois teria se resumido a uma "série de eventos, num certo espaço de tempo, em localidades conhecidas, que os historiadores acharam conveniente abençoar com um nome": o de revolução industrial, como quer Joel Mokyr (1993, p. 2). Devaneios e niilismos que em nada contribuem para a compreensão do fenômeno histórico recoberto pela denominação consagrada.

Em sua configuração insular, apresenta-se como um processo desigual e combinado, porque se fez na convivência dinâmica entre formas arcaicas e formas modernas de produção. Se na longa duração se apresenta como um processo desequilibrado porque combinava fases de crescimento econômico lento com acelerações moderadas (Crafts, 1985), na média duração os momentos de aceleração tornam-se mais perceptíveis, mais nítidos por seus impactos sociais, explicitando a mudança no seio da continuidade, a revolução no bojo da evolução. Momentos de aceleração fundamentais porque estabelecem um novo patamar ao qual se projeta o sistema produtivo, compassando-se às transformações qualitativas na organização social, na ação das forças políticas representadas no Parlamento, na emergência padrões culturais que estabelecem uma nova linguagem por via da qual se expressam as significações. Exatamente o panorama histórico que se observa na Inglaterra quando recortamos na longa duração uma quadra temporal precisa, aquela que corresponde às décadas finais do século XVIII, anos 1780 em diante. Período no qual a dinâmica do sistema econômico repousava sobre a indústria têxtil do algodão, um setor vital que não se viabilizava exclusivamente pela ação de condições endógenas, pois dependia do mercado externo, sobretudo colonial, seja para o fornecimento da matéria-prima estratégica, seja por alavancar o consumo das manufaturas produzidas.

Historiadores de nomeada oscilam em suas interpretações sobre a revolução industrial. Patrick O'Brien $(1982,1998)$, por exemplo, reconhece o lugar de destaque ocupado pela indústria algodoeira na Inglaterra ao longo de dois séculos, mas recusa o ano marco de 1760 como referen- 
cial cronológico que sinaliza o arranque da industrialização, plenamente assumido por uma plêiade de historiadores, sob o argumento de que o mesmo teria se iniciado no mínimo uma centúria antes, nos idos de 1660, explicitando sua adesão ao gradualismo imperante nas hostes dos especialistas na temática de formação econômica. Porém, logo a seguir, no mesmo texto, pondera que no ano de 1760 a indústria têxtil britânica, lastreada no setor algodoeiro, consolidava-se como a primeira concentração fabril do planeta, excluindo-se a Índia, por representar a "manufatura mecanizada mais completa em termos de volume de fios, tecidos e têxteis acabados, manufaturados parcial ou inteiramente a partir das fibras de algodão" (O’Obrien, Griffiths e Hunt, 1991, p. 395). Ou seja, o sistema manufatureiro britânico alcançara um nível de desenvolvimento significativo, um padrão qualitativo diferenciado vis a vis aos padrões pré-existentes. Caracterização esta que nos remete de volta ao significado do ano 1760, previamente recusado, mas, neste passo, aceito como marco simbólico do processo de transformação da indústria britânica em sua trajetória rumo à industrialização madura, por nela reconhecer um diferencial qualitativo, uma ruptura na escala temporal que interrompe o gradualismo em favor da aceleração industrial. Se o primeiro olhar apontava para uma evolução, o segundo reconhece a revolução industrial. Independentemente da definição que se prefira, é forçoso reconhecer a contribuição do algodão em rama oriundo da periferia do sistema para que as mudanças delineadas se verificassem, especialmente a da longínqua colônia brasileira.

\section{LISTA DE REFERÊNCIAS}

AleXAndre, V. (1993). Os sentidos do império: questão nacional e questão colonial na crise do Antigo Regime Português. Porto: Afrontamento.

Arruda, J. J. DE A. (1980). O Brasil no comércio colonial. São Paulo: Ática.

ARRUdA, J.J. DE A. (1986). Commercial trends with the Luso-Brazilian Empire: Brazil's integration in the world market. Em W. FISHER (ed.), The emergence of a world economy 1500-1914: papers of the IX International Congress of Economic History (vol. 1, p. 301). Stuttgart: Steiner Franz Verlag.

ARrudA, J. J. DE A. (1991). Colonies as mercantile investments: The Luso-Brazilian Empire, 1500-1808. Em J. D. TRACY (ed.), The political economy of merchant empires (pp. 360-420). Cambridge: Cambridge University Press.

ARRUDA, J. J. DE A. (2008). Uma colônia entre dois impérios: a abertura dos portos brasileiros 1800-1808. Bauru: EDUSC.

Berg, M. e Hudson, P. (fevereiro, 1992). Rehabilitating the Industrial Revolution. Economic History Review, New Series, 45(1), 24-50. 
Cain, J. P. e Hopkins, A. G. (novembro, 1980). The political economy of Britain expansion overseas, 1750-1914. The Economic History Review, Second series, 33(4), 463-490.

Cain, P. J. e Hopkins, A. G. (1993). British imperialism: Innovation and expansion 16881914. Londres: Longman.

Cannadine, D. (ed.) (2006). Trafalgar in history: A battle and its afterlife. Hampshire/ Nova Iorque: Houndmills.

CRAFTS, N. F. R. (1985). British economic growth during the industrial revolution. Oxford: Clarendon Press.

Crouzet, F. (mars-avril, 1966). Angleterrre et France au XVIIIe siècle: Essai d'analyse comparée de deux croissances économiques. Annales Histoire, Sciences Sociales, 21(2), 254-291.

Davis, L. E. e Engerman, S. L. (2006). Naval blockades in peace and war. Cambridge: Cambridge University Press.

Emmer, P. (1998). The Dutch in the Atlantic economy 1580-1880. Em P. EMmer, The Dutch in the Atlantic economy, 1580-1880. Londres: Ashgate/Variorum.

Fohlen, C. (1973). France 1700-1914. Em C. M. Cipolla (ed.), The Fontana economic history of Europe, IV, The emergency of industrial societies, Part I (Glasgow) (pp. 7-75). Londres: Collins/Fontana Books.

Godechot, J. (1972). L'industrialisation en Europe a l'époque revolutionnarie. Em P. LEON, F. CROUZET, R. GASCON (dirs.), L'industrialisation en Europe au XIX siècle (pp. 7-10). Paris: Édition du CNRS.

Greasley, D. e OXley, L. (1994). Rehabilitation sustained: The Industrial Revolution as a macroeconomic epoch. Economic History Review, 47(4), pp. 760-768.

Heckscher, E. F. (1964). The continental system. Gloucester: Peter Smith.

Hobsbawm, E. (1978). Da revolução industrial inglesa ao imperialismo. Rio de Janeiro: Forense Universitária.

Landes, D. S. (1994). Prometeu desacorrentado. Rio de Janeiro: Nova Fronteira.

LEON, P. (1974). Structure du commerce exterieur et evolution industrielle de la France a la fin du XVIII ${ }^{\mathrm{e}}$ siècle. Em Conjoncture économique, structure sociale. Homage à Ernest Labrousse. Paris: Mouton.

Lima, M. DE O. (1996). Dom João VI no Brasil (3. ed.). Rio de Janeiro: Topbooks.

MAXwell, K. (1993). The Atlantic in the eighteen century: A Southern perspective on the need to return to the 'big picture'. Transactions of the Royal Historical Society, Sixth series, 3, pp. 209-236.

Macedo, J. B. (1982). O Marquês de Pombal, 1699-1782. Lisboa: Biblioteca Nacional.

Maddison, A. (2001). The world economy: A millenial perspective. Paris: OECD.

MOKYR, J. (1993). Editor's introduction: The new economic history and the Industrial Revolution. Em J. MoKYR (ed.), The British industrial revolution: An economic perspective (pp. 1-131). Boulder/San Francisco/Oxford: Westview Press. 
MOKYR, J. (1993). The British industrial revolution: An economic perspective. Boulder/San Francisco/Oxford: Westview Press.

Novais, F. A. (1973). Notas para o estudo do Brasil no Comércio Internacional do fim do século XVIII e início do século XIX (1796-1808). Em L’histoire quantitative du Brésil de 1800 à 1930 (pp. 59-75). Paris: Édition du CNRS.

O'BRIEN, P. K. (1982). European economic development: the contribution of the periphery. Economic History Review, Second series, 35(1), pp. 1-18.

O'Brien, P. K. (1998). A global perspective on industrialization. Economic and Business Review, 25, pp. 9-51

O'Brien, P. K., Griffiths, T. e Hunt, P. (1991). Political components of the Industrial Revolution: Parliament and the English cotton textile industry, 1660-1774. Economic History Review, 44(3), pp. 395-423.

O'Rourke, K. H. (2006). The worldwide economic impact of French revolutionary and Napoleonic wars, 1793-1815. Journal of Global History, 1, 123-149. doi: 10.1017/ S1740022806000076

PIJNING, E. (1997). Controlling contraband: Mentality, economy and society in eighteenth century (Tese do doctor of Philosophy). Johns Hopkins University, Baltimore.

Price, J. M. (1979). Colonial trade and British economic development 1660-1775 (pp. 106-126). Em La révolution américaine et l'Europe. Paris: Éditions de Centre National de la Recherche Scientifique.

Romano, R., (1957). Documenti e prime considerazioni intorno alla 'Balance du Commerce' della Francia dal 1716 a 1780. Em Studi in Onoredi Armando Sapori, vol. II, Milão: Instituto Editoriale Cisalpino.

SIDERI, S. (1978). Comércio e poder: colonialismo informal das relações anglo-portuguesas. Lisboa: Cosmos/Martins Fontes.

Soboul, A. (1976). La reprise économique e la stabilization sociale 1797-1815. Em F. Braudel, E. Labrousse (dirs.), Histoire économique e sociale de la France, vol. 3 (pp. 65-133). Paris: Presses Universitaires de France.

Viennet, O. (1947). Napoléon et l'industrie française: La crise de 1810-1811. Paris: Libraire Plon.

Wilcken, P. (2005). Império à deriva: a corte portuguesa no Rio de Janeiro. 1808-1821. Rio de Janeiro: Objetiva.

\section{Outras fontes}

Arquivo Nacional, Rio de Janeiro, caixas 492 e 493, códices 156 e 157.

Balança Geral do Commercio do Reyno de Portugal com os seus Domínios e Nações Estrangeiras, 1777-1818, Instituto Nacional de Estatística (Lisboa) e Biblioteca Nacional do Rio de Janeiro.

Customs, 4 to 16. Exports and Imports from Great Britain by Countries. Public Record Office/National Archives. 
Dropmore Papers, vol. CCCXXXI, ADD. 59285, dated before 25/june/1806. The British Library Manuscripts Room.

Robert Walpole to Lord Greenville, 12 de outubro de 1791, PRO:FO 6/14. 